\title{
Fotografía y violencia: la memoria actuante de las imágenes*
}

\author{
PHOTOGRAPHY AND VIOLENCE: THE PERFORMATIVE \\ MEMORY OF IMAGES
}

FOTOGRAFIA E VIOLÊNCIA, ATUANDO IMAGENS DE MEMORIA

\section{Vladimir Olaya** \\ Martha Cecilia Herrera***}

Cuadernos de Música, Artes Visuales y Artes Escénicas

/ Volumen 9 - Número 2 / julio - diciembre de 2014

/ ISSN 1794-6670/ Bogotá, D.C., Colombia / pp. 89-106

Fecha de recepción: 27 de mayo de 2014 | Fecha de

aceptación: 5 de octubre de 2014. Encuentre este artículo en

http://cuadernosmusicayartes.javeriana.edu.co/

doi:10.11144/Javeriana.mavae9-2.fvma

* El presente artículo proviene de las pesquisas adelantadas en el marco del grupo de Investigación Educación y Cultura Política, específicamente del proyecto de investigación "Imagen, violencia política y formación: perspectivas de análisis en Colombia" (Código DPG-368-13), financiado por el Centro de investigaciones de la Universidad Pedagógica Nacional.

* Magíster en Educación de la Universidad Pedagógica Nacional (Bogotá, Colombia). Estudiante del Doctorado Interinstitucional en Educación de la Universidad Distrital Francisco José de Caldas, Universidad del Valle y Universidad Pedagógica Nacional (Bogotá, Colombia). Profesor Asociado de la Universidad Pedagógica Nacional. Miembro del grupo de investigación Educación y Cultura Política. Correo electrónico: vlado2380@gmail.com

** Magíster en Historia de la Universidad Nacional (Bogotá, Colombia). Doctora en Filosofía e Historia de la Educación Universidad Estadual de Campinas (Sao Paulo, Brasil). Profesora Titular de la Universidad Pedagógica Nacional. Directora del grupo de investigación Educación y Cultura Política. Correo electrónico: malaquita10@gmail.com 


\section{Resumen}

El presente texto tiene por objeto analizar algunas imágenes fotográficas que, en torno al conflicto armado en Colombia, aparecieron en la página web de la Revista Semana (www.semana.com) en el marco del "Proyecto Víctimas". Desde allí, se pretende observar cómo ellas se constituyen en una forma testimonial $y$, al tiempo, en espacios desde los cuales se movilizan una serie de memorias, modos de ver y comprender la violencia en nuestro país. En pro de lo anterior, en una primera parte se plantea un acercamiento a la comprensión de la relación memoria, imagen y testimonio. En una segunda parte se analizan algunas de las fotografías que aparecieron en lo que se denomina para el portal en línea "semana.com", "Galerías del crimen", específicamente la denominada "Víctimas de masacres" y se observa cómo desde ellas se genera una visualidad individualizada del conflicto, una invisibilización de muchos de sus actores, una despersonificación de los muertos y una deshistorización y vaciamiento de sentido del conflicto armado en nuestro país. Esto se cristaliza en formas de ver que desvelan construcciones éticas y políticas que posibilitan procesos de formación y edificación de culturas políticas.

Palabras clave: fotografía; memoria; Revista Semana; cultura política; violencia política

\section{Abstract}

This article analyses some photographs of the Colombian war conflict that were published in the Magazine Semana a propos the Victims' project. From there, the purpose is to see how these images become testimony and at the same time, sites where memory, forms of seeing, and understanding the violence of the country are mobilized. In the first part of the text the relationship between memory, image and testimony is outlined. In what follows, the analysis takes the photographs as its objects, images that Semana locates in a section called Galleries of Crime. Here it is observed that the images generate an individualized visuality of the conflict, make invisible many of the actors of these events, create an anonymity around the dead, and empty out of sense the Colombian war conflict. This is crystallized through ways of seeing that reveal ethical and political constructs from where political cultures are formed.

Keywords: photography; memory; Revista Semana; political culture; political violence

\section{Resumo}

O objeto do presente texto é analisar algumas imagens fotográficas que, ao redor do conflito armado na Colômbia, apareceram no site da Revista Semana no contexto do "Projeto Vítimas". A partir disso, pretende-se observar como essas imagens acabam se convertendo em uma forma testemunhal e, ao mesmo tempo, em espaços a partir dos quais se mobilizam uma série de memórias, modos de olhar e compreender a violência no nosso país. Em consequência, em uma primeira parte do texto, propõe-se uma aproximação à compreensão da relação memória, imagem e testemunho. Em uma segunda parte, analisam-se algumas das fotografias que apareceram no que se denomina na Revista Semana como "Galerias do crime" e observa-se como a partir delas se gera uma visualidade individualizada do conflito, uma invisibilidade de muitos de seus atores, uma despersonificação dos mortos e uma deshistoricização e esvaziamento do sentido do conflito armando no nosso país. Isto se cristaliza em formas de ver que delatam construções éticas e políticas que possibilitam processos de formação e edificação de culturas políticas.

Palavras-chaves: fotografía; memoria; cultura política; violência política; Revista Semana 
IMAGEN, MEMORIA Y TESTIMONIO

En mi región hay calvarios de ausencia

Muñones de porvenir/arrabales de duelo pero también candores de mosqueta

Pianos que arrancan lagrimas

Cadáveres que miran aun desde sus huertos Nostalgias inmóviles en un pozo de otoño Sentimientos insoportablemente actuales Que se niegan a morir allá en lo oscuro.

Ese gran simulacro, Mario Benedetti (2002, p.13).

¿La imagen fotográfica se puede constituir en un vehículo de la memoria?, ¿ella, la imagen, en tanto interrelación, se puede entender como testimonio?, ¿pueden ser ellas, las imágenes, declarativas de una historia, de una memoria, dicientes de un algo del pasado?, ¿pueden las imágenes coadyuvar a la construcción de una forma de comprender a los sujetos violentados? Estas son algunas de las preguntas que se quieren abordar en la primera parte de este trabajo con el objeto de analizar cómo algunas de las fotografías que de la violencia que circulan en medios de comunicación locales profieren memorias, formas de ver y comprender el conflicto armado en nuestro país.

Desde diferentes perspectivas teóricas, la memoria es una forma de dar sentido al pasado, una construcción que se expresa, en muchas ocasiones, en narrativas que ordenan las percepciones, los sentires y las imágenes de lo vivido. Sin embargo, es necesario decir que dicha memoria también se configura y es resultado de las experiencias y los constructos culturales e ideológicos del momento trasversal presente, pues la posición que se ocupa, el lugar en el que se enuncia es constituido y está afectado por los horizontes de futuro construidos en estadios sociales, culturales y políticos particulares. Ahora bien, ¿qué de eso, de lo narrativo, de las formas de evocar el pasado, puede estar contenido en las imágenes fotográficas de la violencia?

Un estudioso de las imágenes como Didi-Huberman nos recuerda en el texto denominado Imágenes pese a todo (2004), que mucho de la posibilidad de pensar e imaginar lo ocurrido en Auschwitz lo debemos a cuatro imágenes, no porque ellas sean lo único que queda del holocausto, sino porque las imágenes capturadas por los miembros del Sonderkomando, al interior de uno de los campos de concentración nazi, hacían que los relatos de lo inimaginable, como lo enuncia Primo Levi (1989), fueran pensables, creíbles.

Didi-Huberman (2004) enuncia, al principio de su texto, que para hacer memoria hay que imaginar, para recordar hay que construir imágenes, que en el caso de los terribles sucesos en contra de los judíos la palabra no alcanzaba a describir. De hecho, los nazis cometieron una serie de atrocidades con el firme propósito de olvidar, de desterrar las huellas de los sucesos acaecidos. Es decir, el exterminio no tenía que ver solamente con la serie de razones que habían construido los nazis desde lo político, lo cultural y lo económico, sino con la intención de procurar su olvido, de desaparecer todas las presunciones de credibilidad, pues cualquier narrativa de lo sucedido sobrepasaba lo imaginable desde lo humano, lo que las hacía inverosímiles. El exterminio, desde esta perspectiva, tenía también como objetivo la imposibilidad de pruebas que permitieran creer cualquier testimonio, cualquier narrativa. Allí, entonces, la imagen -y en este caso particular las fotográficas- en su doble juego de objetividad-subjetividad 
emergen como testimonio, puesto que, pese al encuadre subjetivo, revitalizan la existencia de un algo.

Desde esta mirada, la imagen fotográfica, especialmente aquella dedicada a registrar hechos violentos, en tanto lenguaje y objeto simbólico, se convierte en una huella de lo sucedido, en un testimonio que pese a su no narratividad, desde la perspectiva de algunos estudios lingüísticos y literarios, nos enfrenta a la existencia de un algo que, sumado a sus interrelaciones con otros hechos y en contextos específicos, nos deja pensar e imaginar de otro modo y desde otro lugar los testimonios, las memorias lenguajeadas de los otros y de las atrocidades.

De hecho, las imágenes filtradas por los Sonderkomando, como lo plantea Didi-Huberman (2004), comprometen toda lectura antropológica y sociológica de lo humano pues ubican sobre la mesa la clara evidencia de la atrocidad y generan la imagen macabra del verdugo como cercano al semejante cometiendo acciones imposibles de creer. Es, en otras palabras, la construcción de un tú, la edificación de una existencia concreta que causa la tortura, la deformación, la desfiguración y la muerte. En este sentido las fotografías se convierten en herramientas que permiten que lo inimaginable sea posible. Al tiempo, las mismas imágenes coadyuvan a inventar otras comprensiones de lo sucedido, a configurar otras memorias.

Ahora bien, las imágenes fotográficas del holocausto, de las vivencias en Auschwitz, a las que hace referencia Didi Huberman, arrebatadas al fenómeno son resultado de la presencia en los hechos de los sujetos fotógrafos. Por medio de ellas es posible identificar las dificultades de la visibilidad, revelado ello en el enfoque y la posición desde las cuales fueron tomadas las fotografías. Ellas, en tanto fenómeno de la visión, muestran el despliegue del sujeto fotógrafo, el tipo de contacto de quien toma las fotos con la realidad, sus incertidumbres y las condiciones que tiene que sobrepasar quien observa y captura la imagen para dejarnos cosas desde las cuales ver, pensar y no olvidar:

(...) arrebatar la imagen escondiéndose en la cámara de gas, arrebatar la imagen escondiendo

el aparato en su mano o en su ropa. Verdad (ante esto, estamos irrefutablemente en el ojo mismo del ciclón) y oscuridad (el humo oculta la estructura de la fosas, el movimiento del fotógrafo vuelve borroso y casi incomprensible todo lo que ocurre en el bosque de abedules).

(Didi-Huberman, 2004, p. 58)

La toma de las imágenes en el trascurrir de los sucesos ubica las fotografías en la misma condición del testimonio, pues son el resultado de un momento subjetivo, consecuencia de la vivencia de una experiencia imborrable y en muchos casos incomunicable. Sin embargo, también son inexactas, como lo plantean algunos historiadores, ya que se constituyen en momentos fragmentarios e incompletos de cualquier verdad, pero es de lo poco que tenemos para hacernos una idea, para imaginarnos, en este caso particular, la vida al interior de los campos de concentración nazi, lo que nos ayuda a construir de otro modo nuestras memorias e historias acerca del holocausto.

En este sentido, podemos pensar las imágenes como un acontecimiento visual, es decir, ellas no solamente muestran lo iconográfico, también dicen del momento, del tiempo y de las condiciones en que son construidas las fotografías ${ }^{1}$. Al igual que los testimonios, ellas declaran silencios, titubeos que se evidencian en su configuración icónica. Simultáneamente, podemos entender la construcción del acontecimiento visual como espacio fenomenológico desde el cual se declara un enunciado, un estado, un espacio, un tiempo. Desde esta perspectiva, la 
fotografía se convierte en un objeto y documento histórico, pues no solo habla de una imagen sino de un acontecimiento que revela unas condiciones de posibilidad que permitieron la construcción y la toma de la imagen en un espacio y tiempo particular.

No obstante, se puede decir que esta disposición de la imagen, elaborada desde el riesgo, como es contado por Didi-Huberman a partir del análisis de la exposición de Clement Cheroux, Memoires des Camps (2001), no es el de todas las imágenes y mucho menos de todas las fotografías, sin embargo, ante cualquier imagen estamos en la constitución y congelamiento de un espacio tiempo del pasado ${ }^{2}$. Cuando miramos cualquier retrato, éste nos perturba, nos señala un espacio, una escena: nos interpela. Ella nos transporta a una situación. Ese es el registro de la temporalidad de las narrativas en tanto nos lleva al lugar de la escena y al tiempo en que fue hecha, a las condiciones que la hicieron posible, a los discursos y acontecimientos que rodean al constructor de la imagen. Así, cuando miramos una imagen (la mirada del otro) nos encontramos ante las reconfiguración de los acontecimientos resultado del entretejido de tiempos disimiles: el tiempo del acontecimiento, el tiempo del sujeto fotógrafo y el tiempo del observador de la imagen. En esta dirección son importantes las alusiones de Benjamin cuando dice:

\footnotetext{
No es necesario decir que el pasado aclara el presente o que el presente aclara el pasado. Una imagen, al contrario, es aquello donde el tiempo pasado se encuentra con el ahora en un relámpago formando una constelación. En otros términos, la imagen es la dialéctica en suspenso. Pues mientras que la relación del presente con el pasado es puramente temporal, continua, la relación del tiempo pasado con el ahora presente es dialéctica: no es algo que se desarrolla, sino una imagen entrecortada. (1982, p. 92)
}

En este sentido, estamos planteando que al mirar nos disponemos ante una forma, delante de una serie de relaciones entre diversos objetos que componen un significado, los cuales al agruparse constituyen un espacio de significación. Ahora bien, la imagen, específicamente la fotográfica, corre inescrutablemente con la carga de ser el espacio en el que se evidencia un "esto ha sido", en términos de Barthes (1990). En otras palabras, son la evidencia de un algo del tiempo que es congelado sin que pueda repetirse pero que logra la supervivencia del pasado, pese a que en muchas ocasiones ella, la imagen, haya sido trasformada, retocada, reconstruida. Así, la imagen fotográfica lleva sobre sí misma la idea de una existencia, presencia-ausencia de un hecho a veces imperceptible en el caos de relaciones que son los fenómenos de la realidad. Por ello la imagen se revela como fantasma en el que es posible exhibir el sufrimiento humano, en muchas ocasiones, a través de una suerte de composición de gestos que dicen de los sujetos, sus latencias, crisis, deseos, rechazos y contratiempos en un espacio del pasado pero que se reconstruye en el presente.

Ahora bien, lo anterior nos dice, por una parte, que la imagen tiene en sí misma una sobre posición de tiempos; ella es el testimonio directo de la existencia de un referente y simultáneamente su expiración, la enunciación de un algo en el ahora sobre el cual dirigir la mirada pero que se pierde en lo que ha sido. Por otra parte, la imagen nos permite la construcción de un saber en tanto deja rememorar, reconstruir, comprender, acercarnos, ya que posibilita la constitución de una serie de relaciones entre lo que sabemos, lo que vemos y lo que podemos imaginar. Lo anterior no quiere decir que la imagen sea una verdad o una realidad. Ella es escasa, no nos muestra el todo, mejor, nos figura las ausencias, nos acerca a la incertidumbre en el 
haz de relaciones que edifica al hacer visible un algo muchas veces imposible de describir. Es por esto que ella, la imagen fotográfica, al construir un haz de relaciones, al proponer un lugar del mirar, admite una ética, pues pone el acento en una forma de ver lo otro y el otro, de construir una lógica del sentido, de estimar lo visible, lo ausente y lo presente que no es otra cosa que una preocupación por el otro y el sí mismo. Recordemos con Ricoeur (1996) que lo ético tiene una fuerte relación con una estima de sí, una solicitud por el otro y un sentido de justicia.

Mediante una fotografía se extiende, entonces, la mirada de un sujeto y la proposición de un mirar, lo cual revela una forma de entender el entre, el mundo que debe ser significado, mirado y objeto de preocupación; es la llamada a revitalizar un algo del mundo. Allí, entonces, encontramos una preocupación por el otro que también es una forma del dar a conocer, puesto que la imagen no se puede separar del observador y ello implica reconocer un punto de vista. En este sentido, mirar la mirada del otro ya es una constitución de una relación, por un lado, pero dejar ver una mirada, por otro lado, es proponer un lugar desde donde ver.

Así, la imagen, más allá de su icónica presencia, construye el testimonio de una existencia, y al tiempo nos presenta la ausencia de algo que ya no es, que estuvo, pero es dicha llamada a la ausencia, a aquello que pasó, enunciado por la imagen, la que se resiste y enfrenta el olvido. Retrae un tiempo, en muchas ocasiones invisible, por ello lo hace presente, convirtiéndose en la posibilidad de su evocación, provocando la ocasión de ser leído, interpretado y encadenado a una red significante, a una narrativa que da la oportunidad de una memoria. Aun así, la presencia de la imagen no sugiere una resurrección en un sentido lato, aunque sí el conocimiento o el vector de una escena de verdad observada.

Desde esta perspectiva, la imagen deconstruye la realidad gracias, aunque suene paradójico, a su posibilidad constructora. Ella permite que irrumpan las miradas trasformando o reafirmando, en algunos casos, nuestras percepciones sobre el mundo a partir de la evidencia y presencia de extrañezas, constituyendo un campo de significación.

La imagen posibilita, al estar inmersa en escenarios semánticos, la reconstrucción de relatos, desde los cuales es posible edificar juicios, interpretaciones de un mundo pasado, de un fenómeno dado que no tiene la posibilidad de volver a ser tal cual como lo evidencia la imagen. Allí resucita el tiempo, lo que permite inducir al espectador a la renovación y construcción de significados, a la visibilidad de aquello que no había sido mostrado, incitándolo a incorporar sentidos y comprensiones. Es este movimiento, la dialéctica entre la presencia de las imágenes y su incitación a ver aquello invisible o tan solo enunciado, lo que posibilita la construcción de una ética, en tanto permite la aparición de un algo sobre lo cual, en muchas ocasiones, no habíamos producido juicios. El reflejo de la imagen elabora un lugar desde el cual mirar y también una forma de relación con aquello presentado, lo que sugiere un saber y actuación ante un fenómeno de la realidad.

En esta lógica también podemos decir que la imagen, y en este caso particular la fotografía, encarna una política, si entendemos que lo político tiene que ver con la constitución de relaciones entre los sujetos y con las posibles:

(...) sentencias de justicia y los actos de controversia democrática -aun en silencio, en la forma de pensamiento y deliberación- no solo son permitidos sino activamente habilitados. (Bal, 2010, p. 46). 
Lo anterior es posible si pensamos que al posicionarnos frente a una imagen, ésta propone un acontecimiento a ser mirado, juzgado. En otros términos, induce a la constitución de una relación, a un modo de estar con eso otro mostrado, signado por valores y sentidos. Con lo dicho, situamos lo político desde su carácter ontológico, es decir, en la forma en que se instituye lo social en tanto tejido y trama desde las cuales los sujetos erigen sus prácticas y encuentros sociales.

Ahora bien, las fotografías en torno a la violencia no están puestas en lo público tan solo para ser observadas y contempladas; ellas estiman la construcción de una sentencia, conducen la acción del ver provocada desde un vértice óptico de la realidad. Es el ejercicio de un posicionamiento espacial ante un algo, pues la apuesta corporal también dice de un posicionamiento frente a lo otro. Recordemos que el cuerpo no es un simple ensamblaje material, conlleva una posición en relación con el mundo. Adicional a ello, la mirada compromete la estimulación de muchos más sentidos. Mirar con el órgano óptico implica una serie de ejercicios cenestésicos, pues, como lo plantea Germán Vargas Guillén (2013), somos cuerpo y, por tanto, posición ante el mundo y sus fenómenos, lo que implica la constitución de un vínculo, la apuesta por un sentido:

\footnotetext{
El cuerpo al tiempo es órgano de la percepción, punto cero y esfera volitiva. Es a partir de este que se espacializa el espacio: las cosas están arriba o abajo, delante o detrás, a izquierda o derecha; pero también es desde el cuerpo que hubo antes y habrá después, es el cuerpo el que temporaliza. Es el que desea y odia, el que experimenta el agrado o la repugnancia; en fin, el que se comprende sexuado con una motivación de ser y de hacer; es, al cabo, la efectuación de la potencia, del conatus; el que se genera y se corrompe. (p. 15)
}

Así, la observación y la mirada implican una experiencia intersubjetiva que no es otra cosa que la configuración de un entre, un devenir de sentido, ya que siempre nos encontramos en comunicación con eso otro presentado y vivenciado. En este orden, la imagen se convierte en un espacio existencial, un intersticio y también una forma de lo social. Allí encontramos lo político, espacio y vector de subjetivación desde el cual se insta una forma del ver-me, el juzgar-me y el narrar-me.

Ante estos enunciados se podría afirmar que se le está atribuyendo demasiado poder a la imagen, sin embargo, lo que se quiere plantear es el papel preponderante que tiene ésta en nuestros espacios sociales, con una serie de efectos sociales y culturales en los procesos de formación de los sujetos. Lo anterior si se advierte que la fotografía, comprendida como lenguaje, se convierte en un lugar existencial que impone, fractura o reafirma un campo de sentido, pero también si se entiende que el ver es una manera de construir un saber, una experiencia del sujeto, aunque para algunos críticos la imagen sea sólo una teatralización del mundo de la vida, pues ella ya nunca será. Aun así, ella es la imposición de un ver construido, es un abstraer del mundo que también posibilita un acontecimiento que en ciertos momentos nos ordena el mundo (o en su defecto lo tensiona, pues su inserción en un campo de lo cultural plantea nuevas relaciones de sentido y a su vez se vuelve parte de ese mismo sistema de relaciones), sus significados e incluso incide, aunque no es el único vector, en las maneras de enfrentarnos a la existencia (de dar sentido) y, en este caso particular, sugiere una mirada en relación con la violencia y las maneras en que la recordamos. 


\section{LAS VIOLENCIAS Y LAS VÍCTIMAS EN LAS IMÁGENES: LAS FORMAS DE MIRAR Y LAS FORMAS DEL RECUERDO}

En Colombia, pese al sinnúmero de tragedias y masacres, las fotografías e imágenes de la violencia nos conducen a observar mucho más que los desastres y al fenómeno en sí mismo, a las víctimas y su dolor. Lo anterior ha llevado -y esta es la tesis que se quiere plantear-a un enfoque en relación con la violencia que olvida las razones de la misma, deshistorizándola de algún modo, volviendo anónimos sus actores, olvidando sus muertos, convirtiéndolos en sujetos desconocidos y procurando de algún modo un alejamiento en relación con las causas políticas, económicas y sociales de las violencias políticas. Sin embargo, las imágenes coadyuvan a la constitución de una memoria que conjuga una serie de des-tiempos y procuran una evocación del dolor como elemento presente.

Ahora bien, las fotografías e imágenes de la violencia que han circulado en nuestro contexto a través de exposiciones y medios de comunicación, se encuentran marcadas por el registro de las huellas y marcas dejadas en los lugares en las que ha tenido ocasión el hecho violento. En otras palabras, son pocas las imágenes que hablan de los sucesos en sí mismos. Si bien esto puede ser explicable por las difíciles circunstancias que significa tomar imágenes en el momento mismo de los acontecimientos, también evidencia una despreocupación por parte de los medios de comunicación de mostrar los fenómenos en su devenir, lo que tendría una serie de efectos en los modos de entender nuestro pasado. En este sentido, tenemos imágenes de nuestra violencia sobre el cuerpo de los dolientes, de los afectados, lo que supone una invisibilización de los actos violentos en sus tiempos y sus significaciones. En cambio, encontramos el tiempo del sufrimiento multiplicado por la resurrección que hace de éste la imagen fotográfica. Así, reconstruimos, como lo plantean algunos autores, entre ellos Sontag (2006), una configuración del miedo como espacio de visibilidad, lo que contribuye a la configuración de una ecología de la incertidumbre que llena los espacios de significación en torno a la violencia política en nuestro país.

Sumado a ello, las imágenes de la violencia que circulan en nuestro entorno, en la mayoría de ocasiones, han aparecido en exposiciones, bienales y en otras, muy pocas, han acompañando artículos de periódicos, prensa o estudios en relación con la violencia política. En otras oportunidades, las imágenes que tenemos de nuestras violencias provienen de trabajos artísticos, lo que sugiere que los lentes que atrapan algunas cosas de nuestro pasado están signados por el encuadre estético, lo que de alguna manera incide en la toma de la imagen, en la forma de poner a circular nuestros sucesos y nuestros recuerdos. Ello hablaría, de alguna manera, de una constitución teatral de nuestra realidad, de un enfoque limitado por el marco de sentido de las empresas de comunicación y de la técnica de la cual es depositario el campo artístico en un momento histórico particular. Esta característica no es de una importancia menor, pues la construcción de la imagen se daría en relación con una forma de ver particular, pero al tiempo tensionada por el fenómeno en sí mismo. Así, la imagen fotográfica contiene las formas culturales y sociales particulares, las cuales se hibridan con los intereses de las empresas de comunicación. En este sentido, diferente a lo planteado por Didi-Huberman, la situación fenomenológica de la fotografía no es la experiencia del acto violento en sí mismo, sino que, al parecer, la experiencia del dolor cobra sentido en relación con los espacios en los cuales van a ser insertas las imágenes fotográficas. La víctima se convierte en un modelo ejemplificante de un fenómeno dotado de sentido por los marcos y capitales simbólicos de 
la mirada del fotógrafo. Así, la víctima pierde su valor como cuerpo testigo y sufriente de un fenómeno histórico, político y cultural, es tan solo una presencia en un algo acaecido. Sumado a ello, la mirada desde la cual se construye la imagen pierde significación, pues ella no es la de un sujeto que vive el hecho, es una enfoque que se distancia del dolor de otros y que tan solo quiere narrarlo. Estamos ante fotografías diestra y profesionalmente elaboradas, lo que refiere la construcción de una mirada que no hablaría, a nuestro parecer, de los tiempos de la violencia ni de aquel que está inmiscuido en el hecho violento, sino de una perspectiva que intenta desvelar los vestigios un hecho, desde una posición trasversal, desde una trama de significaciones dadas al interior de un campo de significación.

Asimismo, es necesario advertir que muchas de las imágenes fotográficas en relación con la violencia en Colombia se han encontrado disgregadas en diferentes medios de comunicación, lo que significa la constitución de una cantidad de trabajos no agrupados, sin que ellas sugieran una temporalidad de la violencia o una narrativa de ésta. De hecho, algunos estudiosos de la violencia y las artes se arriesgan a decir que son muy pocos los trabajos que han intentado historizar la violencia en Colombia desde el arte y la fotografía, olvidando que la perspectiva fotográfica y artística son insumos de gran envergadura para acercarse a entender que la historia de la violencia es una historia del cuerpo de la violencia (Ordoñez Ortegón, 2013). De este modo tenemos, en este tipo de fotografías, la presencia de dos tiempos: el tiempo del fenómeno del dolor y el tiempo del fotógrafo. Sin embargo, dichas temporalidades se presentan paralelas, sin un lugar claramente vinculante, por lo menos en el nivel de la construcción de significados, pues hay, en muchos de los trabajos fotográficos, un alistamiento a dar visibilidad sin que ello implique poner o encadenar una serie de imágenes con pretensiones narrativas o, en su defecto, no existe una relación entre el hecho violento y el ojo del sujeto creador de la imagen, es decir, el fotógrafo registra su ángulo de visión del fenómeno, pero su cuerpo no ha hecho parte, en muchas ocasiones, del acontecimiento.

En este contexto de caracterización de las fotografías de la violencia en Colombia, en mayo de 2013, la Revista Semana publica en su portal web (www.semana.com) el "Proyecto víctimas" ${ }^{3}$, cuyo objetivo fundamental, según lo enunciado en el medio de comunicación es constatar, a través del tal trabajo, la realidad de las víctimas y los desafíos que conlleva su reparación para nuestra sociedad (Revista Semana, 2013). Desde tal enunciado, la revista construye una serie de secuencias fotográficas con el título "Lente y realidad". A través de ellas, la revista anhela, en consonancia con el objetivo del proyecto, exponer y trasmitir el sufrimiento de las víctimas. Tales construcciones, al tiempo, están clasificadas con el nombre de "Crímenes de la guerra". Cada conglomerado de imágenes es nominalizado por alusión a una serie de hechos violentos en el contexto colombiano. Las imágenes fotográficas son agrupadas por temáticas que hacen referencia a masacres, desplazamientos, atentados, desaparición forzada, secuestro, minas antipersonales, reclutamiento infantil, ejecuciones extrajudiciales y afrodescendientes. Las galerías (habitaciones, en su concepción tradicional) están compuestas por una cantidad diversas de imágenes en las que en algunos casos aparece el autor, la fecha de los acontecimientos o frases alusivas a las imágenes publicadas.

En relación con las secuencias fotográficas, que por su disposición se pueden entender como narrativas, es posible decir por lo menos dos cosas. La primera de ellas tiene que ver con el énfasis en el carácter documental de las imágenes (Revista Semana, 2013). En otras palabras, ellas son prueba de los hechos y del sufrimiento de una serie de sujetos, lo que las convertiría en documentos históricos. Pese a ello, esta mención olvida lo que en ellas hay de 
perspectiva y de edificación de una posición ante una serie de fenómenos. Es decir, las fotografías presentadas configuran una relación, proponen una postura ética e instalan un modo de lo político en tanto posibilitan unas formas del ver y del comprender el fenómeno violento. De hecho, el contexto construido por el medio de comunicación en el que se encuentran inmersas las imágenes, signado por el propósito de reparación a las víctimas, nos hacen ver a los sujetos de una forma particular. Ellos son puestos en la arena de lo público como afectados, por su encarnación del dolor y no tanto por lo que los individuos son como parte de una sociedad, con una historia y una perspectiva de los sucesos ocurridos.

El segundo elemento tiene que ver con la manera en que es nominalizada la secuencia fotográfica. Esto es, al vincular las imágenes con un sema como el de la palabra masacres, ellas, las fotografías Ilenan de contenido la manera en que se comprende el hecho violento, pese a que la representación que se construye desde las imágenes son los rastros del suceso, disminuyendo, en cierta medida la dimensión social y política del fenómeno. Así, por ejemplo, al insertar una serie de imágenes al interior de la sala denominada "Galería de víctimas de desplazamiento forzoso"4, las mismas quedan trabadas en dichas denominaciones llenando de contenido la palabra, lo que subordina la imagen a los enunciados del lenguaje escrito, al tiempo que nubla y restringe el sentido de las imágenes fotográficas. Desde esta trama significativa, elaborada por la Revista Semana, lo que tenemos de los acontecimientos violentos, de su verificabilidad, es, por una parte, la imagen de aquel que queda, y, por otra parte, se cubren las razones y los agentes de los fenómenos de la violencia. Se constata una mirada a la realidad de los sujetos, a su dolor (lo que se vuelve la prueba un hecho violento) y no tanto a lo que han significado los mismos hechos para la historia de un país y sus implicaciones sociales y políticas.

En este orden de ideas, la mirada a las víctimas sugiere una focalización y una fuerte importancia a las secuelas y no a la complejidad de los acontecimientos violentos. Si bien ello es apenas lógico y coherente con el objetivo del trabajo propuesto por la Revista Semana a través de su "Proyecto víctimas", la nominalización de dichas secuencias de imágenes nos deja sobre aviso de una toma de posición, nos desvela la construcción desde dónde ver, entender y saber de nuestras violencias, mirada que se construye de lo que nos queda, desde sus huellas. Este no es un dato de menor valor, pues se está, desde dichas fotografías, configurando un modo de rememorar un tiempo y un tipo de situación.

Ahora bien, la unión de fotografías bajo una nominalización sugiere la constitución de una serie de entrelazamientos y relaciones que conlleva la construcción de un campo de sentido. Así, la palabra que nominaliza la galería (Masacres, Desplazamiento, Afrodescendientes, etc.) se ve llenada por la circunstancia que crea y reconstruye la imagen. Allí, la fotografía juega como concepto, como saber, pues restringe, por un lado, cómo pensar la masacre, los actos terroristas, situándolos en los cuerpos de los sujetos. Por otro lado, el acontecimiento pierde una gran cantidad de elementos significativos como la pregunta por el quiénes, por los perpetradores, cerrando de este modo el campo de sentido sobre el cual posicionamos nuestra mirada y nuestros cuerpos. El actor, ejecutor de las masacres, que si bien existe tácitamente y en otras ocasiones tan solo es nombrado en los pies de foto, pierde un lugar significativo en las narrativas que podamos construir desde las imágenes. Es claro que las secuencias de imágenes propuestas no pueden ser valoradas como dispositivos que contienen la totalidad de lo sucedido, no obstante, constatan y configuran sentido desde el dolor sufrido a causa de la guerra. Así, las imágenes y la construcción que se realiza a partir de su entrelazamiento 
con la palabra generan un marco de sentido y al tiempo conciben una posición no solamente corporal sino valorativa que interpela al observador. Con lo anterior estamos planteando que la fotografía, como todo lenguaje, supone una relación que significa cuando pone en posición al otro a quien va dirigida la enunciación (cuando profiero un discurso pongo al otro en un lugar), lo que significa la constitución de una mirada. En esta marco, las fotografías de las víctimas, puestas en la arena pública por el "Proyecto víctimas" constituyen una posición frente a la guerra signada por lo emocional, la individualidad, que es lo dado a ver, a experienciar. En otras palabras, niega lo divergente y oposicional que pueda tener lo social y la guerra suplantándolo por un consenso moral en relación con los sujetos afectados.

Sumado a ello, la imagen entrelazada, montada en una relación con otras fotografías y al interior de un campo temático como el propuesto por la Revista Semana, sugiere una suerte de orden narrativo que escapa a las razones y a causas, y nos deja ver una serie de supervivencias, presencias, que llenan un espacio temporal, no lineal, sino más bien como el conglomerado de un siempre presente.

Las imágenes en las secuencias establecidas en cada una de las galerías sugieren, abruptamente, un atestado de emociones que logran ocupar y dar sentido al tiempo del conflicto, a los fenómenos que testifican la guerra. Sin embargo, las exposiciones de fotografías que se presentan en el portal web del semanario más leído en Colombia no tratan de generar una línea cronológica de tiempo que corra de un punto de la historia a otro. Se trata, en cambio, de enmarcar y construir dicho tiempo en una abigarrada secuencia de gestos de dolor, lo que coadyuva a elaborar la incomprensión, pues solo establecen significativamente parejas de relaciones que se sobreponen, construyendo identidades entre un hecho y una emoción: dolormasacre, dolor-desplazamiento, dolor-atentado. Está allí, la imagen, haciendo la reconstrucción de un pasado, reelaborándolo. Remiten a un otro tiempo no situado, dejando ver aquello inimaginable, pero ahora presente, cercano, adquiriendo la posibilidad de lo real, del esto ha sido, encerrándonos en el puro dolor, pues luego dichas imágenes no podrán arrancarse del alma, de todos los rodeos de la mente. Será infructuoso deshacerse de ellas, de las fotografías y el dolor que contienen, pues siempre nos atraen, vuelven en cualquier meandro de la cotidianidad. De este modo, corremos el peligro de no poder construir los hechos, de no poder entender la trama que contienen los fenómenos mismos tanto para los sujetos sufrientes como para aquellos que nos encontramos frente a dichas imágenes. En este orden, la construcción de una secuencia fotográfica tan enmarañada, sin un marco de tiempo mucho más contextual, solo va a señalar el tiempo de los efectos de la violencia, el tiempo construido por la misma imagen, sin que nos permitan tejer dicho instante con una narrativa dialogante entre el tiempo micro de los sujetos y los macro relatos sociales, de tal forma que coadyuven la edificación de una memoria más comprensiva.

\section{MEMORIAS E IMÁGENES DE LAS MASACRES}

En pro de acercarnos con un poco más de detalle a la forma en que la Revista Semana en su portal web Semana.com construye unas imágenes, memorias y testimonios del conflicto en Colombia a través de las emociones, vivencias de lo que nos queda de nuestro conflicto, hemos querido analizar algunas de las fotografías de la galería denominada "Víctimas de Masacres" ${ }^{5}$. Ella está constituida por un conjunto de 26 fotografías que se entremezclan sin tener un orden cronológico. Lo anterior nos dejan ver, como ya se ha dicho en líneas anteriores, la 
clara intención de no suscribir una temporalidad específica, sino el de desconcertar al espectador a través de la evidencia del dolor como síntoma de un pasado que emerge en la imagen que se resignifica en el presente en tanto testimonio de lo sucedido en nuestra sociedad. Lo anterior posibilita que brote la incertidumbre, la inexplicabilidad, pues la imagen impacta, imprime un shock a la mirada al construir el sentido de los fenómenos a través del padecimiento de los sujetos.

Ahora bien, una primera mirada a la secuencia de imágenes nos viabiliza exponer la existencia de una serie de características que se pueden leer como elementos que ayudan a construir la escena y que inciden en las formas de recordar.

Algunas de las fotografías permiten que la mirada del espectador pueda errar por masas de seres humanos que acompañan féretros en los que los cuerpos de los muertos, en muchas ocasiones, no son visibles, pues la importancia dada por el lente y su focalización se encuentra no tanto en el quién es ese otro difunto sino en la red de dolor que invade las esquinas de nuestros espacios del vivir, pero que deja en silencio quién es aquel que ha desaparecido ${ }^{6}$. Un ejemplo de lo anterior lo podemos ver en la fotografía de Jesús Abad Colorado enumerada como 22 dentro de la galería objeto de análisis en este texto. Dicha imagen tiene un pie de foto en el que se enuncia:

"Paras y militares actuaron juntos en la masacre de San José de Apartadó el 21 de febrero de 2005 con un saldo de 3 niños y 5 adultos muertos" (Abad, Colorado, 2013).

Si bien, la frase que acompaña la foto nos ayuda a identificar los victimarios y a su vez tener una idea de quiénes fueron las víctimas, la forma de nominalizar estos últimos nos dirige a la perdida de su historia, al desvanecimiento del interés por la situación y espacio de relaciones que constituyen los individuos y su rol en la comunidad de la cual eran participes. Paralelo a la enunciación del pie de foto, la imagen sitúa al espectador ante el dolor, delante de la existencia del evento y la afección a una comunidad.

Las fotos presentadas en la galería "Víctimas de masacres" que nos llevan hacia la multitud, en su mayoría, exhiben planos generales y sitúan el ataúd como objeto central. Desde este antiquísimo símbolo del que se fue, de los que se fueron, se despliega el sufrimiento en aquellos que quedan como una red virulenta que los suma, que los hace compartir, que los identifica, construyendo así el sentido de la masacre. Sumado a ello el significado del fenómeno violento se edifica a través del tiempo compartido de la muerte, lo que refuerza la idea de su anormalidad.

El espacio físico, representado en este tipo de imágenes, en términos generales, se ve atiborrado, no permite un espacio en blanco, un descanso, lo que suscita, para la experiencia del espectador, la exaltación de lo imposible, pero a su vez del alejamiento, pues el ángulo del ver, en muchas ocasiones, se ubica en una sobreposición ante el otro, lo cual no es otra cosa que la edificación de la vulnerabilidad y la inferioridad. Sumado a ello, el plano general utilizado es poco vinculante, es un lugar para el dimensionamiento de lo sucedido pero también de la invisibilidad del detalle, la construcción del desencuentro. No obstante, se está allí ante la grandeza de lo sucedido, construyendo y evidenciando la fragilidad de la que somos poseedores y la infinitud del tormento.

A través de este tipo de lenguaje fotográfico, el sujeto perceptor no tiene otra posibilidad sino la de posicionarse ante un hecho que ha sido, ante un síntoma que se difunde, que invade 
y, pese a la posición de superioridad, lo instala, al tiempo, en la soledad y el riesgo. Lo anterior ocurre en razón a que la cercanía de los hechos, la resurrección (no en su sentido cristiano) que provoca la imagen no tiene una explicación de la circunstancia develada que sobrepase el nombre de la masacre y la nominalización de los victimarios. La escena violenta es un fantasma que nos recorre, que construye su presencia ante nuestros ojos.

Desde esta perspectiva, las fotografías que nos muestran la cantidad desvanecen el cuerpo-individuo e intentan, más que presentar a los sujetos, figurar lo inenarrable. En este orden estamos ante lo más abstracto de los seres humanos; la emoción, olvidando y enmascarando, al tiempo, las voces de los sujetos víctimas. En últimas no vemos víctimas, no observamos un hecho, somos seducidos a ver a través de y desde el dolor excesivo. La guerra, como objeto de lo público, se desvanece, es la fusión colectiva del dolor en un tiempo simultáneo lo que se hace digno de recordar.

\section{LA INDIVIDUALIZACIÓN DE LA MASACRE: LA ENCARNACIÓN DEL DOLOR}

Otro tipo de fotografías que conforman la galería denominada "Víctimas de Masacres" se caracteriza por centrarse en el padecimiento individual. Tal tipo de retratos, en su mayoría, ubican a un sujeto en medio de un ambiente hostil, logrado ello a través de planos generales?. La mirada del espectador es ubicada frente a un sujeto apresado en la dolencia y, a su vez, rodeado por un ambiente aciago. Esta interposición de circunstancias logra magnificar el hecho. Si bien podemos decir que el dolor vivido por la muerte de un ser cercano es agudo, el ambiente refuerza dicho significado posibilitando la emergencia y la constitución de lo incomunicable pero con el triste lastre de lo posible para cualquier ser humano. En esta perspectiva, la imagen conlleva la edificación de un lazo de cercanía, de comprensión de lo inimaginable, lo cual, al mismo tiempo, nos permite la presencia del otro en nuestra vida, en nuestro recuerdo. De este modo, la masacre deja de ser un espacio lejano para transformarse en un cuerpo petrificado por el sufrimiento. Como si no fuese suficiente, la imagen queda mucho más reforzada por el peso simbólico que construye, en algunas fotografías, el ángulo del ver en picada lo que conduce a la disminución del otro, el retraimiento de su existencia y la pobreza del ser en la situación del dolor. Dicho mensaje altera los sentidos, nos hace presente la emoción, turba nuestra existencia y profiere una suerte de vinculación, de constitución de un modo de relación con la manera de entender la masacre que está signado por su emplazamiento en la existencia de sujetos particulares.

En otros casos, en los que la masacre es encarnada en situaciones individuales, los rostros del dolor se hacen cuerpo. Es decir, el fenómeno violento es metaforizado a través de la edificación de gestos de descomposición de lo corporal que nos envía a pensar en imposibilidad de sostenimiento anímico. Para ello se acude a figuras simbólicas de carácter universal en el mundo occidental como el de mujer-madre, hermano/a, padre, esposo/a, hijo/a, o la idea de infancia.

El tipo de imágenes que sugieren un rol de los sujetos víctmas al interior de instancias familiares, nos ayudan a pensar en el tipo de relaciones que se fracturan consecuencia de los actos violentos y es ello lo que nos sitúa ante la incomprensión de lo sucedido y la imposibilidad del qué hacer del espectador ante cuerpos insostenibles. 
Ahora bien, en algunas ocasiones este tipo de fotografías, a través de sus pies de foto, hacen enfasis en el nombre de la másacre, la fecha y el grupo responsable del acontecimiento violento, no obstante, tales enunciados no hacen referencia, en la mayoría de ocasiones, por lo menos de manera directa, a las caracerísticas particulares de los sujetos que aparece en la imagen, y cuando lo hacen (en una sola ocasión) la nominalización conduce a comprender al sujeto como parte de una serie de prácticas sociales y culturales que pueden ser ubicadas en cualquier individuo y no en la particularidad de una historia, de unas vivencias. Pese a ello, la vínculación entre el enunciado letrado y el gráfico de la fotografía conducen al espectador a ver en ella los efectos del acto violento. Esto es, la masacre se materializa en unos cuerpos específicos. En este sentido, el tipo de significación construida relaciona un acto masivo con un cuerpo determinado. El suceso que produce esta corporalidad ha sido tan solo enunciado, nominalizado y las razones del mismo, lo que lo produce, es un antes que hemos perdido, que ya no existe. No obstante, la fotografía, como cualquier ejercicio simbólico sin un contexto y una historía mucho más específica nos hace presentir, nos hace imaginar, nos hace ver y construir desde allí una multitud de historias, que en este caso específico logran la edificación de juicios sobre una guerra y unos fenómenos imposibles de sujetar a alguna razón. En otras palabras, las imágenes fotográficas nos dejan sin cohartada, sin razón, pero bajo la construcción de un otro empobrecido no solo moralmente sino material y económicamente, lo que nos ubica en una posición ideológica ante la guerra. En este orden, la representación metafórica del dolor y la masacre a través de cuerpos individualizados es una afrenta a los modos en que dimensionamos y ubicamos la guerra en nuestras cotidianidades y referentes culturales.

La mirada a estos cuerpos del dolor, encadenados por la secuencia de imágenes construidas por el "Proyecto víctimas" nos posiciona, a su vez, en la evidencia de un algo que ha sucedido, que está sucediendo y sobre lo que debemos actuar. Es por ello, quizas, que se presentan, en algunas ocasiones, imágenes en blanco y negro, lo que supone un hecho en un pasado más lejano, pero cuyo sentido se repite en las demás fotografías, aludiendo a diferentes tiempos.

Ahora bien, tal individualización de la violencia tambien sugiere, una invitación al espectador a colocarse en una posición de conmiseración ante el otro, pues el posicionamiento del cuerpo del sufriente, su ceder angustioso ante lo inesperado, ante la muerte, dirige nuestra mirada hacia un valor casi religioso, pues estamos ante la presencia de lo ineluctable. Tal significación nos lía a ellos, en un nosotros sufrientes en contraposión a un otro enemigo, lo que tiene como consecuencia el olvido de lo que tienen de ideológico, económico y político las masacres.

\section{LOS GESTOS SIN ROSTRO: LA EVOCACIÓN DE LA TORTURA}

En la secuencia de imágenes escogida para este análisis, también encontramos una serie de fotografías que nos llevan a la significación de la masacre ligada con la tortura ${ }^{8}$. No obstante, dicha visibilidad profiere, para nosotros, mucho más que un acercamiento al dolor, a una sobreposición del gesto que hace, por su mismo efecto, olvidar a los individuos afectados para mostrarnos la atrocidad de un otro. Es decir, se nos pone ante el dolor, no ante los sujetos. Es la anomia del individuo por el efecto de la tortura lo que se sugiere se constituya como significación y no tanto la identificación de unos individuos sufrientes. 
La revista expone la figura del acto violento, lo que podemos comprender como la espectacularización de la violencia en su extrema teatralización. Dicho sentido es elaborado a través de la evidencia de planos que nos ponen ante el detalle, ante la crudeza y la severidad, ante el terror, ante la magnitud de lo incomprensible e increible, lo que sugiere la experiencia de la sin razón.

Las imágenes nos proponen un angulo de mirada que nos instala en la perplejidad, nos ubica, en tanto espectadores, en el instante, casi que imposibilitados para pensar más allá de lo que ellas nos dejan ver. Dicha disposición pliega y reparte la constitución de una relación ante los hechos que no es fértil para la construcción de razonamientos y, en su lugar, nos instala en la emocionalidad. Es decir, la imagen, pese a la visibilidad que nos propone, ciega, obtura cualquier tipo de racionalidad histórico-argumentativa y engrandece, en cambio, el poder del otro víctimario y su capacidad de hacer y de ser.

La visibilización de la víctima a través de la tortura y el peso simbólico que ella contiene nos detiene ante lo indecible pero es lo que recupera el portal web de la Revista Semana para nuestra memoria, para nuestra historía, "para la dignificación de las víctimas", como lo enuncia el mismo medio de comunicación. Es la turbación del pensamiento lo que se procura a través de este tipo de imagenes y de esta forma se sitúa al espectador ante la imposibilidad de cualquier explicación, lo que no es otra cosa que la edificación de una posición moral y política.

La idea de lo sacrifical que compone este tipo de imágenes y que se va reconstruyendo en el recorrido por los cuerpos que nos proponen las fotografías, nos llevan a la reconstrucción del dolor, y nos da indicios del modo cruel en que diferentes sujetos fueron asesinados. Lo anterior es posible a través de la visibilidad dada a la herida, en algunas ocasiones, a la invasión violenta de los cuerpos, a su segmentación, a la sangre, en otras oportunidades. Este tipo de alusiones realizadas por medio del lenguaje visual nos permiten pensar mucho más en lo brutal del víctimario que en las víctimas, pues la focalización en la acción violenta, en el daño, conlleva a la forzosa construcción de las características del autor del acto violento y su espectacular potencial para causar heridas. De esta forma no estamos viendo solamente a la víctima, estamos construyendo juicios en relación con el victimario, lo que significa entenderlo mucho más como una suerte de enfermo que de un opositor, lo que tiene como consecuencia una despolitización del acto violento.

La figuración de la tortura vehículada a través de la víctima es acompañada, en algunas ocasiones, por la cruz. Este simbolo religioso, como es sabido, ha estado entrelazado históricamente con la configuración de una serie de prácticas sociales, con la construcción de compresiones del mundo que tienen relación con el perdon, la vida eterna y el paraiso, entre otras creeencias. Dichas configuraciones discursivas han servido, en muchas culturas, como elementos esclarecedores del mundo de los individuos y los modos de entender los fenómenos sociales. En este sentido, la aparición de un símbolo como el apuntado y con una carga semántica como la descrita, no se puede entender como un ornato más al interior de imágenes tan fuertes como las evidenciadas en la galería "Víctimas de másacres." Dicho elemento, la cruz, se encuentra relacionado con las formas de comprensión de la muerte, el mal, pero a su vez también es símbolo de esperanza, de salvación y de gloria. En este orden, ante hechos como la mascre y la tortura, y su inexplicable presencia, la cruz y su relación con la salvación, se presenta como un elemento que abre una puerta para la comprensión y actuación ante tales acontecimientos. 
Lo expuesto no juzga, de ningún modo, la fe cristiana o cualquier otra, en cambio se intenta mostrar la manera en que una serie de fotografías que suponen una reivindicación a las víctimas optan, en algunas oportunidades, por una serie de imágenes que conlleva la construcción de visualidades que signan la comprensión del mundo desde posturas que dejan en la esperanza, casi mística, la construcción de un mundo mejor. Se visibiliza, entonces, el poder del víctimario y se deja como marco comprensivo la creencia religiosa.

En este tipo de fotografías ese otro víctima, es un desvalido, un sujeto poseido por el dolor. No es un sujeto que ya no está, que ya ha pasado. La presentación que se hace de la víctima en la arena de lo público es la del silencio, pues el padecimiento es su estado y es lo que lo hace visible y no la idea de un sujeto de la historia y construido por ella. Acorde con lo dicho, las imágenes de nuestras violencias se nos presentan como un saber y un modo de ordenar a través de la lógica de lo inimaginable nuestro pasado reciente, llevándonos casi a negar las posibilidades del otro como un sujeto político.

Sumado a lo anterior, la posición que elaboran las imágenes, en tanto lugares de la mirada y ventanas al mundo, coadyuvan a construir una memoria cuerpo, una memoria sensación que nos encierra en una narrativa del caos, de la existencia del miedo, en la que el pasado no es parte de una historia de larga duración.

No obstante, estas imágenes, memoria y testimonio, nos dicen de un alguien que recuerda pero de una manera que limita, que prefiere el dolor, y que se niega a una contextualización al interior de una historia mucho más política y social, quizás porque se entiende que el dolor y la crueldad son la génesis de la memoria a causa, si se piensa con Nietzsche (1999), de la fatalidad, aquella que no cesa su presencia. Sin embargo, desde allí, desde ese recordar nuestras víctimas, también es factible pensar una memoria que no inmovilice, una memoria que fortalezca un porvenir, una historia que nos junte y nos posibilite. Una memoria que tenga un lugar, un espacio y un tiempo mucho más complejo, no para terminarla, sino que nos ayude a la reconstrucción de las tramas significativas en las cuales se configuran los acontecimientos y las imágenes de las cuales somos depositarios.

En esta medida pensamos que las imágenes fotográficas de la violencia no pueden estar aisladas y situadas desde la fragmentariedad. Es necesario construirlas al interior de narrativas, de historias que evidencien una voz que explicite su lugar; sin embargo, también es necesario optar por imágenes que, políticamente, coadyuven a virar nuestras maneras de ver y vernos, de juzgar y juzgarnos, de narrar y narrarnos, sin dejar que ellas se instalen solo en el momento, sino que, en cambio, nos permitan preguntarnos por los elementos que hicieron posibles las mismas imágenes y los acontecimientos. En otras palabras, optamos por la construcción de imágenes en contextos situados, en campos de sentido que, además de dar evidencia, coadyuven a constituir la palabra para pensarnos otra vez, no solo desde un vértice, sino desde la posibilidad que tiene la misma imagen para lograr otros posicionamientos de los cuerpos que se encuentran frente a ellas. Así, comprendemos que la memoria no es solo un ejercicio de la rememoración, sino, y sobre todo, un ejercicio de la reflexión que constituye espacios de comprensión acerca del momento presente en pro de la construcción de un futuro con el otro y con los otros. 


\section{NOTAS}

1 En este orden de ideas se comprenden las imágenes como lenguaje, el cual adquiere sentido en un contexto determinado, en una situación comunicante, en la interrelación de los sujetos, en un determinado momento histórico, cultural y político. Por lo anterior, entendemos las imágenes como construcciones simbólicas y enunciaciones desde un sujeto ubicado en una situación y con un rol determinado.

2 La instantaneidad, como es propuesta por Didi-Huberman, tendría que ver con la presencia directa en los hechos, con la posibilidad de captar lo sucedido en el momento de su estar dándose. Es sobre esta concepción que se edifica lo que se ha denominado en el ámbito periodístico como reportería gráfica. No obstante, para los autores de este artículo, dicho concepto es problemático por dos razones; la primera de ellas tiene que ver con la idea de instantaneidad y su relación con lo objetivo, como evidencia de lo real, esto es, la presencia en un instante de la vida y su captura a través del aparato fotográfico tiene como consecuencia, en el ámbito de lo social, una significación cercana a la noción de objetividad, a la idea del decir una verdad. Esta noción, cercana a los ámbitos de la ciencia, a sus requerimientos de prueba y comprobación se distancia de una mirada compleja de lo que se denomina como lo real. Para cualquier ser humano, la significación en el evento no se configura solo desde un estar en él, sino en la relación que se constituye entre el ser humano y el evento; de hecho el evento solo es posible en la configuración de tal relación. En este orden de ideas, no hay un hecho objetivo, hay una relación que se establece entre quien mira y documenta un suceso, espacio en el que se da la configuración de la significación. Así, existe una visualidad impuesta a un acontecer, por tanto no hay una realidad, no existe una instantaneidad u objetividad. A su vez, la construcción de la idea de instantaneidad como eje fundamental de la reportería gráfica supone la posibilidad de congelar el tiempo en su realidad, en su devenir. De este modo, se habla de una serie de fotografías que captan el acontecer, no obstante, esto es solo un artilugio del lenguaje, pues el acontecimiento, como es planteado por Deleuze (2011), es una simultaneidad del devenir, es un dándose que no soporta la separación de un antes o un después, es un estadio que avanza en ambos sentidos. Lo anterior incita a pensar que los sucesos en el tiempo no se dan en el eje de una línea recta, sino en una suerte de figura tridimensional que es imposible ver en su totalidad desde cualquiera de sus vértices, pero que, pese a ello, todos los vértices situacionales configuran la existencia del mismo acontecimiento. Así, las imágenes que llamamos instantáneas son en sí mismas perspectivas que declaran una línea transversal del tiempo que atraviesa el acontecimiento y que es construida por la visualidad del sujeto pero que no declara ni una objetividad, ni la totalidad del acontecimiento, por tanto es imposible pensar la imagen fotográfica como objetiva o, en su defecto, como repositorio de la verdad del mundo de la vida.

3 Para una observación del "Proyecto Víctimas," el lector se puede dirigir a la siguiente dirección web: http:// www.semana.com/especiales/proyectovictimas/\#fotos

4 Para observar la galería nombrada, el lector se puede dirigir a la siguiente dirección web: http://www.semana. com/especiales/proyectovictimas/galerias/desplazamiento/index.html

5 Para observar la galería nombrada, el lector se puede dirigir a la siguiente dirección web http://www.semana. com/especiales/proyectovictimas/galerias/masacres/index.html

6 El tipo de fotografías a la cual aludimos en este párrafo se pueden observar en la siguiente dirección web http://www.semana.com/especiales/proyectovictimas/galerias/masacres/index.html.

7 Entre ellas, particularmente las fotografías enumeradas como 9, 13, 22 y 26 . El número de la fotografía se encuentra en el centro de la parte superior de la imagen.

8 Para una mayor ilustración de las apreciaciones realizadas en este apartado, el lector puede observar las fotografías 1, 2 y 15, ubicadas en la galería objeto de estudio (http://www.semana.com/especiales/ proyectovictimas/galerias/masacres/index.html).

9 En relación a este apartado, se invita al lector a observar las imágenes 4, 7, 8,10, 12 y 18, expuestas en la galería Víctimas de Masacres, del Proyecto Víctimas de la Revista Semana (http://www.semana.com/ especiales/proyectovictimas/galerias/masacres/index.html). 


\section{REFERENCIAS}

Abad, Colorado, Jesús. (Fotógrafo). "Paras y militares actuaron juntos en la masacre de San José de Apartadó el 21 de febrero de 2005 con un saldo de 3 niños y 5 adultos muertos". Fotografía ubicada en Galería Víctimas de Masacres, Proyecto Víctimas, Revista Semana [En Línea] http://www.semana.com/especiales/proyectovictimas/galerias/masacres/index.html (Acceso: 16 de agosto de 2013).

Bal, Mieke. "Arte para lo político". Estudios Visuales, [ En línea] núm.7 (enero 2010): 39-66. http:// estudiosvisuales.net/revista/index.htm (Acceso: 16 de junio de 2014).

Barthes, Roland. La cámara lúcida. Notas sobre la fotografía. España: Paidós, 1990.

Benedetti, Mario. El Olvido está lleno de Memoria. Buenos Aires: Editorial Sudamericana, 2002.

Benjamin, Walter. Charles Baudelaire. Un poeta lirico nell'età del capitalismo avanzato. País: Neri Pozza, 1982.

Deleuze, Gilles. La lógica del sentido. Madrid: Paidós, 2011.

Didi-Huberman, George. Imágenes pese a todo. Madrid: Paidós, 2004.

Levi, Primo. Los hundidos y los salvados, trad. Pilar Gomes Bedate. Barcelona: Muchnik Editores, 1989.

Nietzsche, Friedrich. Sobre la utilidad y el perjuicio de la historia para la vida. Madrid: Ed. Biblioteca Nueva, (1999).

Ordoñez, Ortegón, Luisa. "El cuerpo de la violencia en la historia del arte colombiano". Revista Nómadas, Bogotá, núm, 38 (abril 2013): 233-242.

Revista semana. "La reparación de las víctimas del conflicto armado es de una magnitud que pocos países han enfrentado. ¿Podrá Colombia con la tarea?" Revista Semana. [En línea] http://www.semana.com/especiales/proyectovictimas/ (Acceso 16 de agosto de 2013)

Ricoeur, Paul. Sí mismo como otro. España: Siglo XXI Editores, (1996).

Sontag, Susan. Sobre la fotografía, trad. Carlos Gardini, México: Santillana, 2006.

Vargas Guillén, Germán. “Carne e individuación. La deconstrucción fenomenológica del patriarcalismo". Conferencia, Catedra Doctoral Educación y pedagogía. Bogotá: Universidad Pedagógica Nacional, 29 de mayo de 2013.

\section{Cómo citar este artículo:}

Olaya, Vladimir y Herrera, Martha Cecilia. "Fotografía y violencia: la memoria actuante de las imágenes". Cuadernos de Música, Artes Visuales y Artes Escénicas, 9 (2), 89-106, 2014. http:// dx.doi.org/10.11144/Javeriana.mavae9-2.fvma 